\title{
Influence of age on sperm production and testicular weights in men
}

\author{
L. Johnson, C. S. Petty and W. B. Neaves \\ Departments of Cell Biology and Pathology, The University of Texas Health Science Center at \\ Dallas, Dallas, Texas 75235, U.S.A.
}

\begin{abstract}
Summary. Age-related changes in daily sperm production (DSP) and testicular weights were investigated in paired testes from 89 men aged $21-50$ years and 43 men aged 51-80 years. For both DSP/testis and DSP/g parenchyma, remarkably large standard deviations exceeded $50 \%$ of mean values. However, DSP $/ g$ and DSP/testis for both right and left testes were approximately $30 \%$ higher in the younger than in the older group $(P<0.01)$ and were negatively correlated with age $(P<0.01)$ when data from both groups were pooled. Weights of whole testes and of testicular parenchyma were similar in both age groups and were not significantly correlated with age. However, testicular tunic weights were $29 \%$ higher in the older group $(P<0.001)$ and were positively correlated with age $(P<0.001)$. Both testicular tunic weight and the $\%$ of total testis occupied by tunic were negatively correlated with DSP/g $(P<0.01)$; these correlations were weakened by removing the effect of age. Although total testicular weight and testicular parenchymal weight did not change with age, these values were about $10 \%$ lower on the left than on the right $(P<0.001)$. In addition to its increase with age, testicular tunic weight was about $8 \%$ greater for right than for left testes in all men $(P<0.001)$. Although the average size of the testis varied from right to left, DSP/g was similar in paired testes $(P=0.15)$, and the correlation between right and left DSP $/ g$ was high $(\rho=+0.89, P<0.001)$. Much of the variation in daily sperm production in men remains unexplained. However, sperm production does decline significantly with age in the human male.
\end{abstract}

\section{Introduction}

Considerable variation in the seminiferous tubules of individual men has been reported following histological evaluation and quantitative histology (Charny, 1940; Roosen-Runge, 1956; Steinberger \& Tjioe, 1968; Skakkebaek \& Heller, 1973; Honore, 1979; Johnson, Petty \& Neaves, 1981). Likewise, individual variation has been reported in daily sperm production (Amann \& Howards, 1980; Johnson et al., 1980a, b, 1983) and daily sperm output in ejaculates (Hotchkiss, 1941; Freund, 1963; Read \& Schnieden, 1978; Johnson, 1982). The interpretation of sperm production measurements and the evaluation of therapeutic interventions would be enhanced if the variation amongst individual men could be explained. To this end, we evaluated the effects of age on various testicular characteristics.

\section{Materials and Methods}

Pairs of testes from 89 men aged 21-50 years and 43 men aged 51-80 years were obtained throughout the year at autopsy within $24 \mathrm{~h}$ of sudden, unattended death in Dallas, Texas. Cause of 
death was attributed to trauma resulting from accidental or intentionally inflicted injury in $70 \%$ of the younger age group and in $44 \%$ of the older age group. Heart attack or stroke accounted for $15 \%$ of deaths in the younger group and $33 \%$ in the older group. Cause of death was not immediately ascertained in $15 \%$ of the younger men and in $23 \%$ of the older men. Information on ethnic origin was available for $78 \%$ of younger men and $72 \%$ of older men. Among those identified, whites accounted for $60 \%$ and $71 \%$, blacks $33 \%$ and $19 \%$, and latins $7 \%$ and $10 \%$ of younger and older men, respectively. Distribution of men by decade was $46,25,18,22,12$, and 9 proceeding from the 3 rd to the 8th decade of life.

Air-tight containers were used to store frozen testes until evaluated by phase-contrast cytometry of homogenization-resistant spermatids in homogenates of unfixed testicular parenchyma. The time interval between death and freezing (post-mortem time) varied between 3 and $24 \mathrm{~h}$ and was examined for relationships to other data gathered in the study. The time of year in which death occurred was also recorded and examined for possible seasonal influence on daily sperm production. Upon thawing, each testis was separated from the epididymis and fascia, weighed to the nearest $0.01 \mathrm{~g}$, decapsulated, and homogenized in a Waring Blender for $2 \mathrm{~min}$ in $150 \mathrm{ml} 150 \mathrm{~mm}$ $\mathrm{NaCl}$ containing $0.05 \%$ Triton X-100 and $2.8 \mathrm{~mm}^{-\mathrm{NaN}_{3}}$ (Amann \& Lambiase, 1969).

Duplicate enumerations of homogenization-resistant spermatids were made by each of two evaluators. The daily sperm production per testis (DSP/testis) was calulated as the number of homogenization-resistant spermatids in the homogenate divided by the 2.9-day estimated life span of such spermatids (Johnson et al., 1981). The life span is based on the duration of these spermatids in human spermatogenesis (Clermont, 1963; Heller \& Clermont, 1964). The DSP/testis value divided by the parenchymal weight provided DSP/g. Precision, measured by the average coefficient of variation, was $11 \%$ for repeated estimates of DSP $/ g$ for the same testes.

Differences between age groups and between right and left testes were assessed by parametric and non-parametric tests of significance. In no case did the level of significance of difference vary according to whether parametric or non-parametric tests were applied. Since values for several of the measurements exhibited skewness within groups being compared (see Text-fig. 1), results of

\section{Young men Old men}

(a) $\mathrm{DSP} / \mathrm{g}\left(10^{6}\right)$

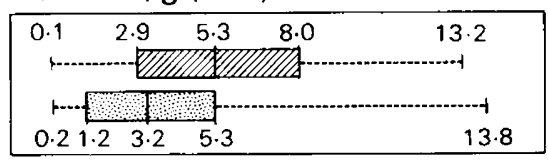

(b) DSP/testis $\left(10^{6}\right)$

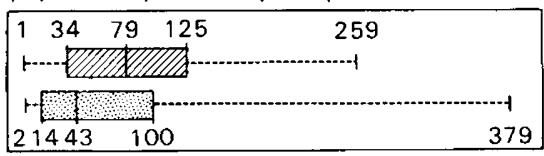

(c) Testis wt. (g)

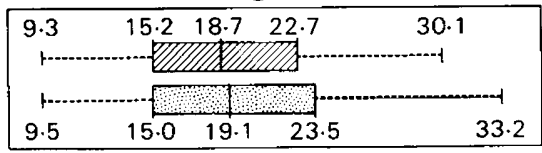

(d) Parenchyma wt. (g)

\begin{tabular}{|c|c|c|}
\hline $6 \cdot 5$ & $\begin{array}{lll}12.1 & 15.0 & 18.1\end{array}$ & $25 \cdot 0$ \\
\hline & VIIIXIIITA & $\cdots$ \\
\hline 5.8 & $11.414 .0 \quad 18$ & 27.4 \\
\hline
\end{tabular}

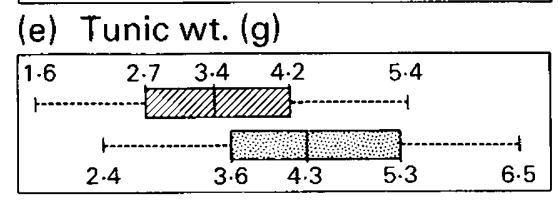

(f) \% of testis as tunic

\begin{tabular}{|r|r|}
\hline 11.116 .717 .920 .0 & 30.7 \\
17.520 .123 .327 .3 & \\
\hline
\end{tabular}

Text-fig. 1. Comparison of sperm production and testicular weights in right testis of younger and older men by Tukey's (1977) box-and-whiskers plots. These graphical representations of variation within groups of study subjects display minimum, 25th percentile, median, 75th percentile, and maximum values for each characteristic. Plots based on data from left testes closely resembled those based on right testes. 
non-parametric significance tests are reported throughout this paper. For comparisons between age groups, the Mann-Whitney test has been used (Zar, 1974). The Wilcoxon test was employed for comparisons between paired right and left testes (Zar, 1974).

Regression analysis was performed on many of the characteristics measured from all 132 men in this study. Parametric (Pearson's $r$ ) and non-parametric (Spearman's $\rho$ ) correlation coefficients were tested for significance (Zar, 1974). In only one case did the two correlation coefficients yield different significance levels. For age versus DSP/testis, calculation of $\rho$ rather than $r$ increased the significance level from $P<0.01$ to $P<0.001$ and from $P<0.05$ to $P<0.01$ for right and left testes respectively. Since normal distribution of values could not be assumed in many cases, Spearman's $\rho$ is reported throughout this paper. Study of pairwise correlation of various testicular measurements was extended to partial correlations (Draper \& Smith, 1981) with the effect of age removed from each.

Since considerable variation in all measurements occurred in both age groups, the following description of results applies to groups and not to individuals within the groups.

\section{Results}

Both testes of older men had values for DSP/g and DSP/testis that were $27-33 \%$ lower than corresponding values in younger men (Table 1). Sperm production expressed both per gram and per testis was negatively correlated with age for all men in this study (Table 2; Text-fig. 2a). Weights of whole testes and of testicular parenchyma were similar in both age groups (Table 1) and were unrelated to age (Table 2). However, weight of the testicular tunic was increased by $28 \%$ in both testes of men in the older age group (Table 1) and was positively correlated with age (Table 2). When expressed as percentage of total testicular weight, the testicular tunic was $35-39 \%$ heavier in the testes of men in the older age group (Table 1) and exhibited a significant positive relationship to age when both groups were subjected to regression analysis (Table 2). Exaggerated thickness of the

Table 1. Comparison of sperm production and testicular weights in younger and older men

\begin{tabular}{|c|c|c|c|}
\hline & \multirow[b]{2}{*}{ Testis } & \multicolumn{2}{|c|}{ Age } \\
\hline & & $21-50$ years & $51-80$ years \\
\hline No. of men & & 89 & 43 \\
\hline $\mathrm{DSP} / \mathrm{g}\left(10^{6}\right)$ & $\begin{array}{l}\text { Right } \\
\text { Left }\end{array}$ & $\begin{array}{l}5.59 \pm 0.36 \\
5.26 \pm 0.34\end{array}$ & $\begin{array}{l}3.72 \pm 0.48^{* * *} \\
3.80 \pm 0.48^{* *}\end{array}$ \\
\hline DSP/testis $\left(10^{6}\right)$ & $\begin{array}{l}\text { Right } \\
\text { Left }\end{array}$ & $\begin{array}{l}85.5 \pm 5.9 \\
73.8 \pm 5.2\end{array}$ & $\begin{array}{l}59 \cdot 7 \pm 9 \cdot 9^{* *} \\
53 \cdot 8 \pm 8 \cdot 2^{* *}\end{array}$ \\
\hline Testis weight $(\mathrm{g})$ & $\begin{array}{l}\text { Right } \\
\text { Left }\end{array}$ & $\begin{array}{l}18.9 \pm 0.5 \\
17.2 \pm 0.5\end{array}$ & $\begin{array}{l}19.2 \pm 0.9 \\
17.5 \pm 0.9\end{array}$ \\
\hline Parenchyma weight (g) & $\begin{array}{l}\text { Right } \\
\text { Left }\end{array}$ & $\begin{array}{l}15 \cdot 5 \pm 0.4 \\
14 \cdot 0 \pm 0.4\end{array}$ & $\begin{array}{l}14.8 \pm 0.8 \\
13.5 \pm 0.8\end{array}$ \\
\hline $\begin{array}{l}\text { Tunic } \\
\text { weight (g) }\end{array}$ & $\begin{array}{l}\text { Right } \\
\text { Left }\end{array}$ & $\begin{array}{l}3.44 \pm 0.09 \\
3.17 \pm 0.09\end{array}$ & $\begin{array}{l}4.39 \pm 0 \cdot 16^{* * *} \\
4.06 \pm 0.16^{* * *}\end{array}$ \\
\hline$\%$ of testis & $\begin{array}{l}\text { Right } \\
\text { Left }\end{array}$ & $\begin{array}{l}18.4 \pm 0.3 \\
18.8 \pm 0.4\end{array}$ & $\begin{array}{l}24 \cdot 9 \pm 1 \cdot 1^{* * *} \\
26 \cdot 1 \pm 1 \cdot 4^{* * * *}\end{array}$ \\
\hline
\end{tabular}

Values are reported as mean \pm s.e.m.

${ }^{*} P<0.05,{ }^{* *} P<0.01,{ }^{* * *} P<0.001$ compared with value for younger men (Mann-Whitney non-parametric test). 

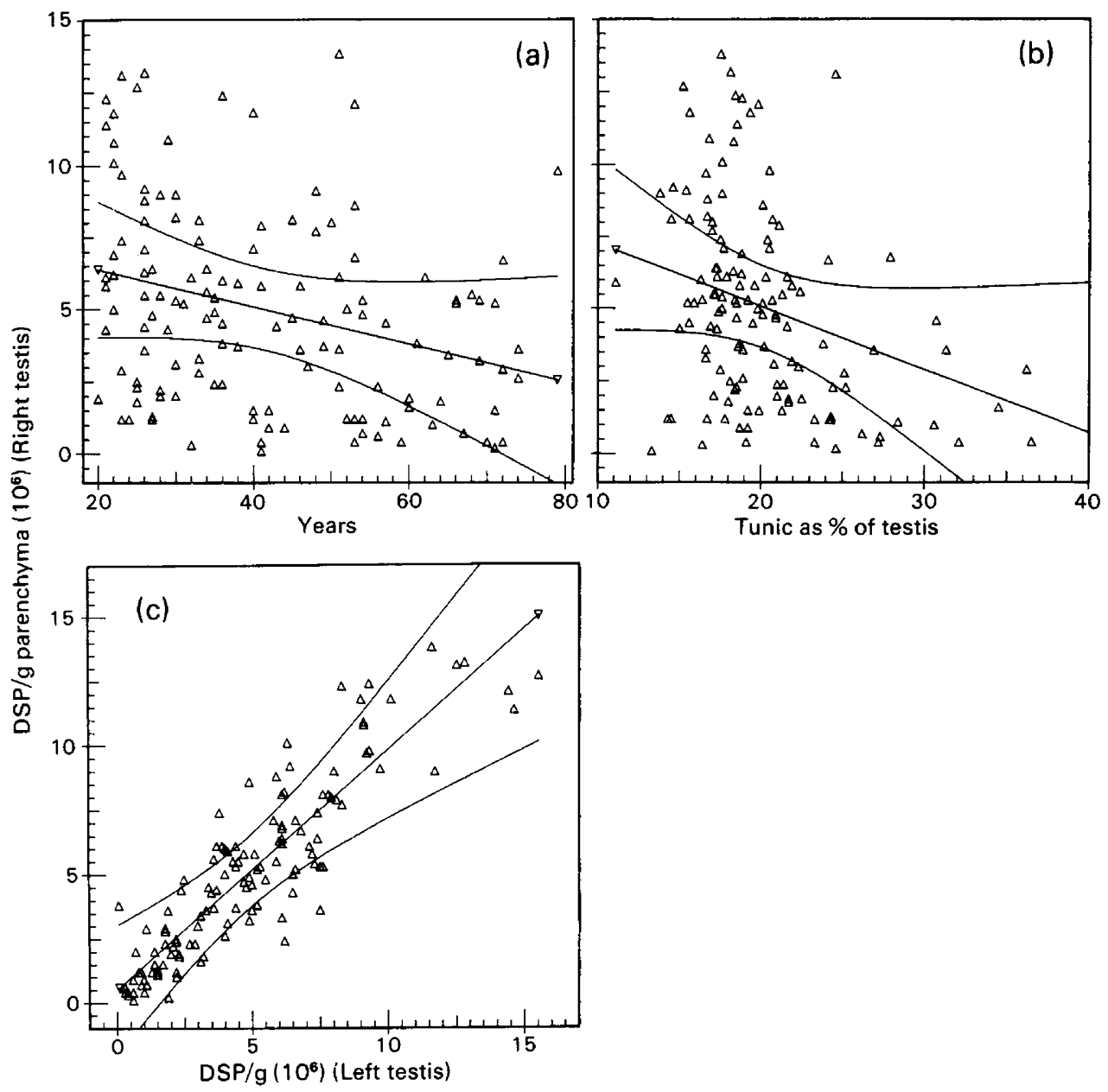

Text-fig. 2. Sperm production in the right testes of 132 men in relation to (a) age, (b) tunic development and (c) sperm production in the left testis. The regression lines, drawn with $95 \%$ confidence limits, are (a) $y=7.7-0.065 x(\rho=-0.33)$, (b) $y=9.5-0.22 \times(\rho=-0.39)$ and (c) $y=0.50+0.86 x(\rho=+0.89)$.

tunic, due largely to accumulation of fibrous tissue, was responsible for the elevation in weight with increasing age.

Values for DSP/testis were positively correlated with total testicular weight and with weight of the testicular parenchyma (Table 2). However, neither testicular weight nor parenchymal weight was related to DSP/g (Table 2). The opposite was true of the relationship between testicular tunic weight and sperm production. DSP/testis was unrelated to tunic weight; however, DSP/g was negatively correlated with tunic weight (Table 2). The negative relationship between tunic development and sperm production became more apparent when tunic weight was expressed as a percentage of total testis weight (Table 2; Text-fig. 2b). Calculation of partial correlation coefficients to remove the effect of age revealed a weaker association between tunic development and daily sperm production (Table 2 ).

Average post-mortem time was the same for both age groups $(12.8 \pm 0.8 \mathrm{~h}$ for the younger 
group and $12.9 \pm 1.0 \mathrm{~h}$ for the older group; $P=0.95$ ), and subject age was unrelated to postmortem time $(\rho=-0.06, P=0.48)$. There was no relationship between post-mortem time and $\mathrm{DSP} / \mathrm{g}$ for the right or left testis $(\rho=-0.01, P=0.91$ and $\rho=+0.00, P=1.00$, respectively).

Although human males may experience some seasonal variation in semen composition (Pinatel, Czyba \& Souchier, 1982), there was no significant difference in DSP/g between winter (December, January, February) and summer (June, July, August) for the younger ( $N=16$ in winter and $N=$ 25 in summer) or older $(\mathbf{N}=13$ in winter and $\mathbf{N}=11$ in summer) age groups. At the latitude where these specimens were collected $\left(33^{\circ} \mathrm{N}\right)$, the average winter temperatures range from 3 to $15^{\circ} \mathrm{C}$ and the average summer temperatures range from 23 to $35^{\circ} \mathrm{C}$. The results were the same regardless of whether right or left testes were analysed $(P>0.05$ in all cases).

Testicular weight and parenchyma weight averaged $9-10 \%$ lower on the left as compared to the right (Table 3). Testicular tunic weight averaged $8 \%$ lower on the left as compared to the right (Table 3). The DSP/g was similar in each testis, but the DSP/testis was $13 \%$ lower in the left testis (Table 3). Regression analysis revealed close correlation between paired testes for all

Table 2. Results of regression analysis between age and various testicular values and between combinations of testicular values in 132 men from 21 to 80 years of age

\begin{tabular}{|c|c|c|}
\hline & \multicolumn{2}{|c|}{ Correlation coefficients $\dagger$} \\
\hline & Right testis & Left testis \\
\hline $\begin{array}{l}\text { Age versus } \mathrm{DSP} / \mathrm{g} \\
\text { Age versus } \mathrm{DSP} / \mathrm{testis} \\
\text { Age versus testis weight } \\
\text { Age versus parenchyma weight } \\
\text { Age versus tunic weight } \\
\text { Age versus } \% \text { testis as tunic }\end{array}$ & $\begin{array}{l}-0 \cdot 33^{* * *} \\
-0 \cdot 31^{* * *} \\
+0 \cdot 05 \\
-0 \cdot 03 \\
+0 \cdot 38^{* * *} \\
+0 \cdot 53^{* * *}\end{array}$ & $\begin{array}{l}-0 \cdot 25^{* *} \\
-0 \cdot 26^{* *} \\
+0 \cdot 03 \\
-0 \cdot 05 \\
+0 \cdot 39^{* * *} \\
+0 \cdot 52^{* * *}\end{array}$ \\
\hline $\begin{array}{l}\text { Testis weight versus } \mathrm{DSP} / \mathrm{g} \\
\text { Testis weight versus } \mathrm{DSP} / \text { testis }\end{array}$ & $\begin{array}{l}+0.02 \quad(+0.04) \\
+0.32^{* * *}(+0.35)\end{array}$ & $\begin{array}{l}+0.05 \quad(+0.06) \\
+0.39^{* * *}(+0.41)\end{array}$ \\
\hline $\begin{array}{l}\text { Parenchyma weight versus } \mathrm{DSP} / \mathrm{g} \\
\text { Parenchyma weight versus } \mathrm{DSP} / \text { testis }\end{array}$ & $\begin{array}{l}+0.08 \quad(+0.10) \\
+0.38^{* * *}(+0.39)\end{array}$ & $\begin{array}{l}+0.13 \quad(+0 \cdot 12) \\
+0.46^{* * *}(+0.46)\end{array}$ \\
\hline $\begin{array}{l}\text { Tunic weight versus } \mathrm{DSP} / \mathrm{g} \\
\text { Tunic weight versus } \mathrm{DSP} / \text { testis }\end{array}$ & $\begin{array}{ll}-0.23^{* * *} & (-0.12) \\
+0.01 & (+0.15)\end{array}$ & $\begin{array}{ll}-0.23^{* *} & (-0.15) \\
+0.01 \quad(+0.13)\end{array}$ \\
\hline $\begin{array}{l}\% \text { Testis as tunic versus } \mathrm{DSP} / \mathrm{g} \\
\% \text { Testis as tunic versus } \mathrm{DSP} / \text { testis }\end{array}$ & $\begin{array}{l}-0.39^{* * * *}(-0.27) \\
-0.44^{* * *}(-0.34)\end{array}$ & $\begin{array}{l}-0.42^{* * *}(-0.35) \\
-0.53^{* * *}(-0.48)\end{array}$ \\
\hline
\end{tabular}

† Spearman's $\rho$ (values in parentheses are partial correlation coefficients with the effect of age removed).

${ }^{*} P<0.05,{ }^{* *} P<0.01,{ }^{* * *} P<0.001$ for values compared with zero.

Table 3. Comparison of various testicular values for the paired left and right testes of 132 men from 21 to 80 years of age

\begin{tabular}{|c|c|c|c|}
\hline & Right testis & Left testis & $\begin{array}{l}\text { Correlation } \\
\text { coefficients }(\rho)\end{array}$ \\
\hline $\mathrm{DSP} / \mathrm{g}\left(10^{6}\right)$ & $4.98 \pm 0.30$ & $4.79 \pm 0.28$ & $+0.89 \dagger$ \\
\hline DSP/testis $\left(10^{6}\right)$ & $77 \cdot 1 \pm 5 \cdot 2$ & $67 \cdot 3 \pm 4.5^{*}$ & $+0.87 \dagger$ \\
\hline Testis weight (g) & $19.0 \pm 0.5$ & $17 \cdot 3 \pm 0.4^{*}$ & $+0.80 \dagger$ \\
\hline Parenchyma weight $(\mathrm{g})$ & $15 \cdot 3 \pm 0.4$ & $13.8 \pm 0.4^{*}$ & $+0.80 \dagger$ \\
\hline \multicolumn{4}{|l|}{ Tunic } \\
\hline weight (g) & $3.75 \pm 0.09$ & $3.46 \pm 0.09^{*}$ & $+0.83 \dagger$ \\
\hline$\%$ of testis & $20.5 \pm 0.5$ & $21 \cdot 1 \pm 0.6$ & $+0.82 \dagger$ \\
\hline
\end{tabular}

Values are mean \pm s.e.m.

* $P<0.001$ compared with value for right testis (Wilcoxon non-parametric test).

$+P<0.001$ for values different from zero. 
characteristics measured (Table 3). The highest correlation between right and left paired testes was found for DSP/g (Table 3; Text-fig. 2c).

\section{Discussion}

The remarkably large variation (s.d. $>50 \%$ of the mean) found in DSP/g and DSP/testis is consistent with the large variation in human spermatogenesis previously noted by other workers (Charny, 1940; Roosen-Runge, 1956; Steinberger \& Tjioe, 1968; Skakkebaek \& Heller, 1973; Honore, 1979; Johnson et al., 1981). The reasons for this large variation are poorly understood. However, in agreement with reported trends (Amann, 1981), our study indicates that age contributes to this variation. Indeed, the age-related changes in both DSP/g and DSP/testis were significant in our study.

Evidence suggestive of declining sperm production with advancing age comes from several sources. Ejaculation rates decline from 3 per week for ages 15-30 to $<1$ per week for age 70; furthermore, the number of spermatozoa per ejaculate is reduced by $30 \%$ in the 7 th decade of life and by another $20 \%$ in the 8 th decade (see review by Hafez, 1976). The length of time required for development of spermatozoa from spermatogonia in man is not altered from 74 days regardless of age (Heller \& Clermont, 1964). However, while $90 \%$ of the sectioned profiles of seminiferous tubules contain spermatids in the $3 \mathrm{rd}$ and 4 th decades of life, only $50 \%$ do so in the 5th to 7 th decades, and in men over 80 years of age a mere $10 \%$ of the tubules contain spermatids (Sasano \& Ichijo, 1969).

Degenerative changes within seminiferous tubules of ageing men have been summarized by Bishop (1970) and Harman (1978). The major changes, in order of occurrence and severity, include thickening of the basement membrane and tunica propria of seminiferous tubules, followed by decreased spermatogenic activity. The physiological status of the basement membrane and tunica propria is crucial (Timiras \& Meisami, 1972). With ageing, new layers of connective tissue are deposited and the wall thickens. This thickening is deleterious to formation of spermatozoa and probably underlies the gradual decline in spermatogenesis with senescence (Timiras \& Meisami, 1972). With progression of fibrosis in ageing, the germinal epithelium becomes increasingly separated from the blood supply (Bishop, 1970).

The thickening of the testicular tunic observed in older testes in our study is a reflection of the established testicular propensity to undergo progressive fibrosis with increasing age. The fact that tunic weight exhibited a significant negative relationship to sperm production suggests that similar factors may be responsible for increased tunic thickness and decreased DSP/g. A common metabolic deficiency, such as reduced oxygen tension in the testis, could perhaps increase fibrosis and, directly or indirectly, also reduce production of spermatozoa.

It is also possible that the age-related decline in the Leydig cell population (Kaler \& Neaves, 1978) and apparent reduction in testosterone production (Harman, 1978) may be involved in the lowering of sperm production noted in the present study. Testosterone is required for the completion of meiosis during spermatogenesis (Steinberger, 1971), and sperm production rates in humans are closely related to the percentage of cell loss during post-prophase of meiosis (Johnson $e t$ al., 1983). A reduced production of testosterone could lower sperm production rates by increasing cell loss during meiosis. More potential correlates of age-related changes in the testis must be investigated before causative relationships are attempted.

Contrary to the results of the present study, which found no change with age in either total testis weight or parenchyma weight, several previous studies have reported decreased testicular weight and/or volume in older men (see review by Harman, 1978). However, Tillinger's (1957) study of 299 men from 16 to 90 years of age showed no diminution of testicular weight with increasing age if the seminiferous tubules were intact. If the tubules were disregarded, testicular weight diminished only after 60 years of age (Tillinger, 1957). When Tillinger (1957) divided his subjects into the age groups 
used in our study, testicular weights in the younger and older groups were similar, regardless of the condition of the seminiferous tubules.

This present series of men also provided an opportunity to examine the relationship between right and left paired testes. The results show that left testes are significantly smaller than right testes. This is true for weights of parenchyma and tunic as well as for total testis weight. The magnitude of the difference is about a $10 \%$ reduction in weight on the left side. In spite of the tendency for the left testis to be smaller, weights of testicular components are highly correlated between the right and left sides. Although it varies widely amongst men, DSP/g is remarkably similar between paired testes. Both DSP/g and DSP/testis exhibit a highly positive correlation between right and left testes. However, due to the smaller size of the left testis, it produces fewer spermatozoa on average than the right. The striking similarity in sperm production per gram by both testes of individual men implicates governing influences that transcend each testis. Assuming similar blood flow through each organ, both testes of a pair should experience similar levels of gonadotrophic stimulation and similar access to metabolic substrates. Likewise, the testicular response to these conditions will be predicated on the same genetic heritage (for an example of the potential significance of common genetic heritage on daily sperm output in man, see Johnson, 1982). Equally importantly, both testes are subject to the same influences of life-style, environment and vicissitude. The relative importance of these potential supratesticular influences is as yet unproven, but these are also the same factors that vary so widely from individual to individual, thus providing potential explanation for the striking variation in sperm production amongst men.

This work was partly supported by NIH grants RR07175 and AG02260.

\section{References}

Amann, R.P. (1981) A critical review of methods for evaluation of spermatogenesis from seminal characteristics. J. Androl. 2, 37-58.

Amann, R.P. \& Howards, S.S. (1980) Daily spermatozoal production and epididymal spermatozoal reserves of the human male. J. Urol. 124, 211-215.

Amann, R.P. \& Lambiase, J.T., Jr (1969) The male rabbit. III. Determination of daily sperm production by means of testicular homogenates. J. Anim. Sci. 28, 369-374.

Bishop, M.W.H. (1970) Ageing and reproduction in the male. J. Reprod. Fert., Suppl. 12, 65-87.

Charny, C.W. (1940) Testicular biopsy: its value in male sterility. J. Am. med Assoc. 115, 1429-1433.

Clermont, Y. (1963) The cycle of the seminiferous epithelium in man. Am. J. Anat. 112, 35-51.

Draper, N.R. \& Smith, H. (1981) Applied Regression Analysis, 2nd edn. John Wiley, New York.

Freund, M. (1963) Effect of frequency of emission on semen output and an estimate of daily sperm production in man. J. Reprod. Fert. 6, 269-286.

Hafez, E.S.E. (1976) Reproductive senescence. In Aging and Reproductive Physiology, pp. 1-19. Ed. E.S.E. Hafez. Ann Arbor Science, Michigan.

Harman, S.M. (1978) Clinical aspects of aging of the male reproductive system. In The Aging Reproductive System, Vol. 4, pp. 29-58. Ed. E. L. Schneider, Raven Press, New York.

Heller, C.G. \& Clermont, Y. (1964) Kinetics of the germinal epithelium in man. Recent Prog. Horm. Res. 20, 545-575.
Honore, L.J. (1979) Testicular biopsy for infertility: a review of sixty-eight cases with a simplified histologic classification of lesions. Int. J. Fert. 24, 49-52.

Hotchkiss, R.S. (1941) Factors in stability and variability of semen specimens: observations on 640 successive samples from 23 men. J. Urol. 45, 875-888.

Johnson, L. (1982) A reevaluation of daily sperm output of men. Fert. Steril. 37, 811-816.

Johnson, L., Petty, C.S. \& Neaves, W.B. (1980a) A comparative study of daily sperm production and testicular composition in humans and rats. Biol. Reprod. 22, 1233-1243.

Johnson, L., Petty, C.S. \& Neaves, W.B. (1980b) The relationship of biopsy evaluation and testicular measurements to over-all daily sperm production in human testes. Fert. Steril. 34, 36-40.

Johnson, L., Petty, C.S. \& Neaves, W. B. (1981) A new approach to quantification of spermatogenesis and its application to germinal cell attrition during human spermiogenesis. Biol. Reprod. 25, 217-226.

Johnson, L., Petty, C.S. \& Neaves, W.B. (1983) Further quantification of human spermatogenesis : germ cell loss during postprophase of meiosis and its relationship to daily sperm production. Biol. Reprod. 29, 207215.

Kaler, L.W. \& Neaves, W.B. (1978) Attrition of the human Leydig cell population with advancing age. Anat. Rec. 192, 513-518.

Pinatel, M.C., Czyba, J.C. \& Souchier, C. (1982) Seasonal changes in sexual hormones secretion, sexual behavior and sperm production in man. Int. J. Androl., Suppl. 5, 183-190. 
Read, M.D. \& Schnieden, H. (1978) Variations in sperm count in oligozoopermic or asthenozoospermic patients. Andrologia 10, 52-55.

Roosen-Runge, R.C. (1956) Quantitative investigations on human testicular biopsies. I. Normal testis. Fert. Steril. 7, 251-261.

Sasano, N. \& Ichijo, S. (1969) Vascular patterns of the human testis with special reference to its senile changes. Tohoku J. exp. Med. 99, 269-280.

Skakkebaek, N.E. \& Heller, C.G. (1973) Quantification of human seminferous epithelium. 1. Histological studies in twenty-one fertile men with normal chromosome complements. J. Reprod. Fert. 32, 379389.

Steinberger, E. (1971) Hormonal control of mammalian spermatogenesis. Physiol. Review 51, 1-72.
Steinberger, E. \& Tjioe, D.Y. (1968) A method for quantitative analysis of human seminiferous epithelium. Fert. Steril. 19, 960-970.

Tillinger, K.G. (1957) Testicular morphology. Acta endocr., Copenh., Suppl. 30, 1-192.

Timiras, P.S. \& Meisami, E. (1972) Changes in gonadal function. In Developmental Physiology and Aging, pp. 527-541. Ed. P. S. Timiras. Macmillan Co., New York.

Tukey, J.W. (1977) Exploratory Data Analysis. AddisonWesley, Reading, Massachusetts.

Zar, J.H. (1974) Biostatistical Analysis. Prentice-Hall, Eaglewood Cliffs.

Received 19 May 1983 